Living Tangier 
CONTEMPORARY ETHNOGRAPHY

Kirin Narayan and Alma Gottlieb, Series Editors 


\title{
LIVING TANGIER
}

\author{
Migration, Race, \\ and Illegality \\ in a Moroccan City
}

Abdelmajid Hannoum

\author{
PENN \\ UNIVERSITY OF PENNSYLVANIA PRESS \\ PHIL A DEL PHIA
}


Copyright (C) 2020 University of Pennsylvania Press

All rights reserved. Except for brief quotations used for purposes of review or scholarly citation, none of this book may be reproduced in any form by any means without written permission from the publisher.

$$
\begin{gathered}
\text { Published by } \\
\text { University of Pennsylvania Press } \\
\text { Philadelphia, Pennsylvania 19104-4112 } \\
\text { www.upenn.edu/pennpress }
\end{gathered}
$$

Printed in the United States of America on acid-free paper 135579108642

A Cataloging-in-Publication record is available from the

Library of Congress

ISBN 978-0-8122-5172-2

LCCN 2019020159 
For Gabriel Asfar 
